\title{
China and its Region: An Assessment of Hegemonic Prospects
}

\author{
Srđan Vučetić (GSPIA, uOttawa)
}

Prepared for "Six decades of the Past - Six decades for the Future" International conference celebrating sixty years of teaching

\& researching International Relations in Slovenia (»Šest desetletij za preteklost, šest desetletij za prihodnost « Mednarodna konferenca ob 60-letnici poučevanja in raziskovanja mednarodnih odnosov v Sloveniji)

\section{University of Ljubljana \\ 8-9 October 2021}

\section{1,000 words}

Will China's rise lead to Chinese hegemony? Most International Relations scholars would answer in the negative, contending the road to a global hegemony remains well beyond Beijing's interests and capabilities. In Asia, however, China's formidable economy, technological advancement, rapidly modernizing military forces, and recent geopolitical moves look outright hegemonic - a fact that United States attempts to "pivot" and "rebalance" to that region have put into sharp relief. To assess the prospects of a new regional hegemony, this paper considers the "economic," "security" and "cultural" relations of eleven Asian states with both Beijing and Washington. The overall results induce skepticism about the latter's ability to reorder the region. Although growing and in some cases significant, China's provision of international goods to neighboring countries still pales in comparison to that centered on the United States and its allies. Sightings of an Asian Pax Sinica are at best premature.

Acknowledgments: For data collection assistance and written comments, thanks go to Ebby Abramson and Caroline Dunton, and for translations of Chinese language data sources to Yang Xuantong and Sinan Chu. For data visualization help with Figures 1-4, I thank Miloš Popović. Excellent comments and criticisms came from Ted Hopf, Amit Julka, Manali Kumar and members of the Asia Research Institute at the National University of Singapore, where parts of this paper were first presented. I am also grateful to everyone who made time to read the subsequent drafts, including Christina Lai, Nebojša Bjelaković, and Gregorio Bettiza. 
In April 2021, Montenegro entered the chronicles of the so-called debt-trap diplomacy. When the European Union (EU) rejected an appeal from Prime Minister Zdravko Krivokapić's government for help in repaying the US $\$ 1$ billion Chinese loan that the previous government signed in 2014, the Balkan nation found itself face-to-face with a much-increased risk of debtdependency that some say is at the heart of Beijing's vaunted Belt and Road Initiative (BRI). Thus, rather than making progress towards EU membership, Montenegro came close to joining a club of "BRI victims" - Sri Lanka, Pakistan, Djibouti and other countries unlucky countries whose governments are, or could soon be, forced to sign over assets with national and strategic importance to the People's Republic of China's (PRC) main lending organ, the Export-Import Bank of China. ${ }^{1}$

This episode indexes a key question of contemporary geopolitics: Will the rise of China's economy ultimately lead to Chinese hegemony? ${ }^{2}$ Riding on the wings of its dazzling economic growth, the PRC has advanced not only BRI projects, but also a series of military ones: the modernization of the nuclear arsenal, the rollout of new stealth, cyber and artificial intelligence warfare technologies, the construction of the world's second-largest blue-water navy, and the building of new overseas bases. And all this comes on top of a renewed territorial feud with India, "hostage diplomacy" against Canada, retaliatory economic pressure on Norway, South Korea, Australia and the Philippines, dangerous saber-rattling directed at Taiwan, aggressive maritime "land reclamation" in the South China Sea, naked attempts to manipulate public opinion abroad through social media and "wolf warrior diplomacy," and the effort to exert evergreater control over international organizations, old and new alike.

Significant as these developments are, the majority view among International Relations (IR) scholars and think tank executives is that a full-scale Chinese hegemony is unlikely. Their

\footnotetext{
1 The Montenegro story generated countless "hot takes" in the Western media (e.g., Fukuyama 2021). By July, US and French banks jumped in to refinance the loan, thus (temporarily) lowering the risk of a debt crisis. Antidotes to BRI debt-diplomacy sensationalism include Hurley, Morris, and Portelance (2018), Kapstein, Caverley and Vucetic (2019), Jones and Hameiri (2020) and Wong (2021). Recent studies of China's influence in the Balkans include Vladisavljev (2021), Andjelic (2020) and Apostolov-Dimitrijevic (2020).

2 The steady growth of this literature can be gleaned from Kang (2007), Mabee (2013), Ikenberry, Wang, and Zhu, eds. (2015), Massie and Paquin, eds. (2019), and Feng and He, eds (2020). Indeed, for reasons of style, I follow a commonplace practice of conflating "PRC" with "China" and "US" with "America."
} 
reasoning revolves around three basic arguments: the PRC is nowhere near as materially powerful as presented in the news media; its capacity to actually mobilize leadership of a global order remains severely limited; and - BRI and new aircraft carriers notwithstanding - the government in Beijing is interested in "partial hegemony" at best. ${ }^{3}$ If even one of these claims is correct, the Montenegrins, Sri Lankans, Pakistanis, and Djiboutians need not learn Mandarin just yet - at least not all of them at once.

What of the peoples living closer to China? However they might define "China's region" as "East Asia," "Western Pacific," "Asia-Pacific," or "the Indo-Pacific” - IR scholars would agree that the PRC's bid for regional hegemony is significantly stronger. ${ }^{4}$ For the first time ever, the Pentagon's own reports are saying that the People's Liberation Army would not lose to the US in a conventional shooting war along China's coastline, including over Taiwan. World Bank reports, in turn, are saying that China's economy already accounts for more than half of Asian GDP, and that China's development financing in the region has already surpassed that of the World Bank itself. And President Xi Jinping is saying that cultural and "civilizational" ties matter, too. Going back to foreign language studies, we indeed see South Korea and Japan leading the world in the study of Mandarin. Then there is Singapore, of course, where over four decades ago the national government introduced a series of measures to ensure its citizens learn the PRC's official language. ${ }^{5}$

Where in this region are China's hegemonic prospects strongest and where are they weakest? To provide a preliminary answer to this question, I focus on eleven East and Southeast Asian states - Japan, South Korea, Laos, Cambodia, Indonesia, Malaysia, Myanmar, the Philippines, Singapore, Thailand, and Vietnam. Guided by Alexander Cooley and Daniel Nexon's analytically eclectic IR framework for analyzing international hegemony, ${ }^{6}$ I examine these states' relations with both the PRC and the United States (US), the region's most powerful

\footnotetext{
${ }^{3}$ For discussions, see especially Norrlöf and Poast (2020), Rolland (2020), Pu (2019), Johnson (2019), Beckley (2018), Allan, Vucetic, and Hopf (2018), Wang, ed., (2017), and Chen (2016).

${ }^{4}$ Loke (2021), Chong (2020), Turner and Parmar, eds (2020), Goh (2019), Lai (2018), Liang (2018), Zhang (2018), Hoo (2018), Walton and Kavalski, eds (2017), Beeson and Li (2014), Kang (2007), Shambaugh, ed. (2006).

${ }^{5}$ For further context, see Chong (2020).

${ }^{6}$ Cooley and Nexon (2020). It follows that the present paper does not adjudicate arguments distilled from seemingly competing "schools" of IR theory.
} 
“external player” and an "incumbent global hegemon.” I conclude that the PRC's bid for hegemony in Asia rests on shaky foundations at best. The states most likely to join the PRC-led order are three "minor powers": Laos, Cambodia, and Myanmar. The remaining eight are likely to stay out of Beijing's orbit - and this is a group that runs the gamut from the wealthy, technologically advanced, and democratic US "treaty allies” to an ethnic Chinese majority city state under one-party rule. ${ }^{7}$ Although provisional, this conclusion is of relevance to both scholarship and policy: although China's rise has had, and will have, massive geopolitical consequences, Chinese hegemony need not be one of them, even in Asia, at least in the foreseeable future.

The rest of the paper proceeds as follows. Part I defines hegemony and outlines the proposed theoretical framework. Part II lays out the study's research design and data. Parts III$\mathrm{V}$ discuss regional hegemonic relations from the perspective of, respectively, "economic," "security," and "cultural" goods. Part VI summarizes the main findings and relates them to a selection of recently published think tank studies. The paper concludes with a speculative look at future of international ordering in Asia and beyond.

\section{Hegemony}

Contemporary IR defines hegemony as a mobilization of leadership of an international order, which in turn refers to regular, lasting, and relatively stable patterns of action and interaction among states and other actors. Accordingly, when most IR scholars write of the socalled "rules-based", "liberal" or "US-led" international order, they do not mean a discrete, bounded, and differentiated "thing" so much as a constellation of relations and practices. ${ }^{8}$ They also accept, at least tacitly, that "US hegemony" operates differently across different "issue

\footnotetext{
${ }^{7}$ Compare this with many Western media reports of states in Asia either "playing both sides" or "shifting toward to China" (e.g., Fisher and Carlsen 2018). The study deliberately puts aside the discussion of balancing, hedging, hiding and related concepts some scholars use to describe and proscribe relations among states (e.g., Zhang 2018).

${ }^{8}$ Cooley and Nexon (2020: 32) rightly prefer the term international ordering, since the verb is better able to denote the order-generating interaction between the rules, norms, and values (what they call "architecture") on one hand, and everyday routines, flows, and practices ("infrastructures") on the other (also see Chowdhury 2018 and Johnson 2019). Much of IR theorizing of hegemony remains centered on hegemonic stability theory and the nearby power transition theory (Ibid.: 211, n. 30; Andersen, Cooley, and Nexon, eds, 2021, Allan, Vucetic and Hopf 2018: 842-3).
} 
areas" as well as across different "levels" of interaction involving state, substate, nonstate and/or international actors.

As Cooley and Nexon explain, US hegemony has faced a series of structural challenges over the years: the so-called Sputnik moment in 1957; the breakup of the Bretton Woods system in the early 1970s; the ignominious withdrawal from Vietnam in 1975; and the assorted anxieties about an "emerging Japanese superstate" and Washington's "imperial overstretch" in the 1980s. None of these came close to ushering a "post-American world." But now that rising Chinese juggernaut is coalescing with a number of other counter-hegemonic, multipolarityworshipping forces, we see that "this time is different" and that "the United States...will need to accommodate other powers to a much greater extent than it is used to."9

Will Chinese hegemony in Asia be part of this accommodation? To begin to answer this question, my analysis focuses on the authors' concepts of "patronage monopoly" and "international goods substitution." 10 In their analysis, the shift in economic power shifts towards the PRC and other emerging powers has already killed the Western near-monopoly - or cartel over the provision of economic, security, cultural and other goods. We see this today in the distribution of everything from development loans, emergency finance, diplomatic protection, election monitoring, military hardware, and COVID-19 vaccines. The 2021 military coup in Myanmar can serve as an example. The reaction of most Western diplomats was to issue a series of individual and joint condemnations. In Washington, the new Biden-Harris administration went a step further, calling for new sanctions and threatening to isolate the country even more than in 2017, when sanctions were applied in response to the atrocities the Myanmar government committed against Rohingya Muslims. Beijing took the opposite stance. Rather than join the chorus against the military takeover, PRC diplomats moved to defend Myanmar against human-rights criticisms in the United Nations (UN) Security Council. For most observers, this was both predicted and predictable. In addition to a long-standing commitment

${ }^{9}$ Cooley and Nexon (2020: 1, 201).

${ }^{10}$ Ibid.: 62-4. Further theoretical elucidation is in Andersen, Cooley, and Nexon, eds (2021) and in Cooley, Nexon, and Ward (2019). 
to "non-interference" in international affairs, the PRC has no shortage of business interests in the country, including the oil and gas pipelines that run from the PRC through Myanmar to the Indian Ocean. ${ }^{11}$

The example shows how interstate patronage bargains work: Myanmar's military junta was well-positioned to leverage ties with the PRC in exchange for diplomatic protection in the UN. It also shows that the very availability of PRC-supplied goods - economic, diplomatic, and normative - provided Myanmar with “exit options," and the West with no options when it comes to imposing Western order. We see similar developments in all four corners of the world, with more and more states escaping the power of the US and Western-dominated institutions of global governance by moving closer to China, Russia and other alternative international goods providers. This trend will only continue. The Chinese economy, all being equal, is slated to become the world's largest by about 2030, and possibly the world's largest source of both inbound and outbound foreign direct investment. ${ }^{12}$ Non-Western goods provision will increase further if Beijing succeeds in dominating the fields of artificial intelligence, quantum computing, $5 \mathrm{G}$ telecommunications and future new technologies.

Following Cooley and Nexon's framework, I set out to observe the changing dynamics of interstate patronage potential in Asia by focusing on three baskets of goods - "economic," "security," and "cultural." 13 I do so on an assumption that the structures and processes that constitute said goods contain useful information for assessing hegemonic prospects. The supply-and-demand logic involving the first two baskets is straightforward: the more $\mathrm{X}$ is dependent on the hegemon-supplied "guns and butter," the more likely X is to become a follower of that hegemon. Cultural goods are harder to define. Rather than items of self-

\footnotetext{
11 Prashad (2021). China's interference in Myanmar's decades-old civil war is too complex to detail here or, in fact, anywhere in contemporary IR (Brenner and Han 2021), but we can safely assume that the public is more resentful of Beijing than the military establishment ruling the country.

12 Adjusting to purchasing power parity, the Chinese economy has been the world's largest since 2014.

13 Goods can further be classified as private, common-pool, club or public (Cooley and Nexon 2020: 42, 222, n.94, Andersen, Cooley, and Nexon, eds, 2021, cf. Prys 2010, Kapstein, Caverley and Vucetic 2019). Designed to synthesize the common logics across IR theories as well as sidestep the field's (meta-)theoretical agony over the materialideational "distinction," these categories are by default inseparable parts of a complex whole. Development aid and the conditions that accompany it include certain security and ideological commitments, just as an arms deal is never just about security but also has economic and symbolic value (A Bourdieusian conceptualization of goods, for one, would stress their performative dimension, or "capital" [Andersen, Cooley, and Nexon, eds 2021]). The purpose of dividing these processes into three rubrics is simply to reduce complexity to facilitate analytical communication.
} 
evidently great artistic or historical import, cultural goods in this case are more akin to "soft power" and "cultural diplomacy" - that is, to educational, artistic, and scientific "products" that shape, and are also shaped by, the dynamics of international leadership and followership. ${ }^{14}$ This is why the PRC invests heavily not only in BRI projects and new international organizations but also in everything from the English-language radio, television, print and social media (e.g., $@$ XHNews on Twitter) to cultural institutions and events (e.g., Confucius Institutes, blockbuster movies such as Wolf Warrior II) to "vaccine diplomacy" and political training programs for government officials. ${ }^{15}$ Some IR scholars would say that cultural goods are crucial because they tap directly into the social bases for hegemony, or its ideological underpinnings. The US and the West at large have long understood this, too: make your own ideology attractive to the world, and the world will be more likely to acquiesce to your leadership. ${ }^{16}$

Though the present study builds on assumptions about rational state action under conditions of interdependence, it is worth noting that circulation of cultural goods is not confined to a particular privileged spatial scale. Take the assorted a-liberal, non-liberal, and illiberal challenges to "liberalism" as the dominant ideology of the U.S.-led Western order. ${ }^{17}$ Officially, the PRC offers a set of ideological alternatives to Western-style liberalism by emphasizing, in the words of its leaders, "justice," "mutual respect," "inclusivity," and "peaceful co-existence," or, in the words of Western observers, "political capitalism," "authoritarian capitalism," "techno-authoritarianism," "sovereignism," and "civilizationism."18 But some of the

\footnotetext{
${ }^{14}$ Building on the previous footnote, soft power and cultural diplomacy are functions of hegemonic socialization, which in turn occurs via successful provision of security and economic goods (Cooley and Nexon 2020: 43). 15 By early 2021, over $60 \%$ of China's global vaccine supply went to Southeast Asia alone (Gilani 2021). Also see Chu et al (2019), Benabdallah (2020), Edney et al (2020), Popovic, Jenne, and Medzihorsky (2020), and ETNC (2021).

${ }^{16}$ Given that hegemonic relations are always tenuous and contested, the hegemon cannot simply coerce its clients into adopting economic and security policies conducive to its interest but must also achieve a degree of consent. In this regard, some IR theorists follow the insights of the Italian Marxist thinker Antonio Gramsci, particularly his "cultural hegemony." Cooley and Nexon (2020: 233-234; fn. 62) explicitly disengage from neo-Gramscian IR but see, inter alia, Allan, Vucetic and Hopf (2018) and Graaff et al (2020).

17 The "liberal" international order, as Cooley and Nexon (2020: 21-3) explain, is a shorthand that conflates very different configurations of liberalism as well as different issue-specific orders (Johnson 2019). Example: the "neoliberal" theory of state design that emerged in the 1980s coalesced with the "liberal intergovernmentalist" architecture of the 1990s but not with liberal democratic politics at the national level (Chacko and Jayasuriya 2017). 18 The phases in scare quotes would take too much space to define, but for context see Weiss and Wallace (2021), Milanovic (2020), Ching (2020), Paris (2020), Graaff et al (2020), Bettiza and Lewis (2020) and Pu (2019). It was in 2013 that the Chinese Communist Party released a memorandum known as Document 9, which openly critiques "Western constitutional democracy," free press and the idea of universal values (Buckley 2013; also see Hoo 2018).
} 
"same" alternatives circulate within and across Western societies. ${ }^{19}$ These hegemonic

contestations are often mutually reinforcing. The PRC's commitment to "civilizational diversity", for example, has a great deal of common ground with the position of radical conservative parties, think tanks, study groups, conferences, online platforms, and front organizations that operate nationally and transnationally. ${ }^{20}$ How these different hearts-and-minds battles interact, and with what consequences for regional and global orders are two crucial questions, albeit ones that fall outside the scope of the present analysis. ${ }^{21}$

\section{Research Design and Data}

For the purposes of this study, I define "China's region" as consisting of eleven nations: Japan, South Korea, Laos, Cambodia, Indonesia, Malaysia, Myanmar, the Philippines, Singapore, Thailand, and Vietnam (for a map of this region, see Figure 3 below). The definition is both principled and pragmatic. Principled, because all of them are identified by themselves and others as Asian, with the last nine being Association of Southeast Asian Nations (ASEAN) members as well. They are also quite heterogenous in terms of wealth, democracy, relative military capabilities, demography and other characteristics that are said to matter for the relationship between the distribution of goods on one hand and regional orders on the other. Pragmatic, because every analysis must begin and end somewhere. The tiny sultanate of Brunei is omitted, as are North Korea and Taiwan - the first as an autarkic PRC client, the second for being ontologically anti-PRC. ${ }^{22}$ Laos, in contrast, is included in spite of the incomplete data.

The same sense of pragmatism shaped my temporal focus as well. Though focused on the period between 2010 and 2017 for reasons of data availability, I extended the analysis

\footnotetext{
${ }^{19}$ Cooley and Nexon (2020: Ch. 6). Also see Chacko and Jayasuriya (2017) and Abrahamsen et al (2020).

${ }^{20}$ Even PRC and US officials sometimes find themselves in the "same" ideological coalition. Months after Chinese ambassador to Ottawa Lu Shaye in 2019 called Canada and its allies white supremacists (CBC 2019), then Director of Policy Planning at the US State Department, Kiron Skinner, went on record to say that the PRC challenge to US dominance was different because "[i]t's the first time that we will have a great power competitor that is not Caucasian.” For some context, Vucetic $(2011,2021)$ and Búzás (2020).

21 As David C. Kang (2007) has pointed out years ago, an "ideal” analysis of hegemony would account for prevailing structural patterns while also remaining sensitive to the contestable and contingent nature of the relationship between international orders on the one hand and the evolving identities of the states and societies that constitute those orders on the other (cf. Weiss and Wallace 2021, Johnston 2019, Allan, Vucetic, and Hopf 2018).

${ }^{22}$ For the latter claim, see Sterling-Folker (2009).
} 
backward and forward in time whenever contextually appropriate, which in this case was often, given the changes wrought by the COVID-19 pandemic and the US presidencies of, respectively, Donald Trump and Joe Biden. ${ }^{23}$

To operationalize the regional provision of "economic goods," actual or potential, I use three types of data sourced either from reputable international institutions, such as the World Bank, or from national governments: standard trade data, including total trade as a percentage of GDP between each country under study and China, and each country and the US; direct foreign investment (FDI) data, and debt-dependence data, that is, data on how dependent each country under study is on BRI-related loans. ${ }^{24}$ For "security goods", I turn to research on alliances, partnerships, joint military exercises, basing agreements, arms transfers, and related military ties that many argue constitute the bedrock of Asia's security governance today. Much of the quantitative data I use here come from the Stockholm International Peace Research Institute (SIPRI). The SIPRI Arms Transfer Database, for one, is invaluable because it covers eleven categories of "major conventional weapons," with detailed information about the type, number, and approximate financial value of systems. ${ }^{25}$

Next, I use cross-national public opinion data to get a sense of a possible distribution of "cultural goods." 26 The most widely used source is the Pew Global Attitudes project. ${ }^{27} \mathrm{~A}$ commonly used tool for estimating "US standing in the world" - one proxy for the legitimacy of US hegemony -, Pew data allow us to make over-time comparisons of the percentages of respondents with favorable views of the PRC and/or of PRC leaders, as well as compare these figures to the equivalent figures for the US and US leaders. In this case, the data is available only

\footnotetext{
23 The period allows us to observe the effects of key foreign policy changes in both Beijing and Washington associated with, respectively, Xi's rise to power in 2012 (Hoo 2018: Ch.5) and the "pivot" to Asia in 2011 (Silove 2016).

${ }^{24}$ Supplementary files provide links to raw data: https://srdjanvucetic.files.wordpress.com/2021/04/chinas-regionsuppl.pdf Most of the data comes from sources made publicly available at various international governmental and non-governmental institutions. Only FDI data was collected directly from government sources.

25 The institute's website is https://www.sipri.org/ See also "SIPRI Arms Transfers Database - Methodology," https://www.sipri.org/databases/armstransfers/background/.

${ }^{26}$ Each is a tentative choice until more appropriate indicators of cultural hegemony become available. Promising in this regard is Making Identity Count (Hopf and Allan, eds, 2018), an IR project to assemble a database of national identities. See in particular https://www.makingidentitycount.org/mic-asia

27 The Pew Research Center launched its "Pew Global Attitudes Project" in 2001. Latest reports and commentary can be found at: http://pewglobal.org.
} 
for six nations under study: the Philippines, South Korea, Japan, Vietnam, Malaysia and Indonesia. I augment this source with analyses using other survey data sources as well.

In the final step I put aside the artificial distinction between economic, military and cultural goods to take a closer look at votes cast in the UN General Assembly (UNGA). Thanks in large part to the work of Erik Voeten and his colleagues, UNGA voting records are now commonly used in IR as a way of "revealing” general foreign policy orientation or, indeed, convergence of foreign policy preferences. ${ }^{28}$ In theory, every vote is an opportunity to demonstrate either the firmness of national interests (through, for example, signalling loyalty to existing alliances and alignments) or their malleability (as when regime change occurs). Governments pay close attention to these signals themselves. ${ }^{29}$ Accordingly, I take voting choices in the world's largest deliberative body to be a potentially a useful source of information about patterns of international leadership and followership at either global or regional scale. Simply put, the more consistently a state in the region votes in line with the PRC in the UNGA, the greater the likelihood of that state being tied to PRC goods, whether security, economic or cultural.

\section{Economic Goods}

Over the past several decades, China's share of global trade has been increasing at a dizzying pace. Having knocked off the US from the top spot already in 2013, China in fact managed to maintain a leading role in global supply chains even throughout the COVID-19 pandemic. Regional data affirm this picture. Looking at imports, we see Myanmar and Cambodia leading the pack by consistently relying on China for more than a third of their imports since 2010, with the other countries hovering between 10\% (Laos in 2015, for example)

\footnotetext{
${ }^{28}$ On the study of world politics using UNGA voting data, see Voeten (2013) and Bailey, Strezhnev and Voeten (2017), and the database at https://dataverse.harvard.edu/dataset.xhtml?persistentId=hdl:1902.1/12379 Also see analyses of the conditions under which the US and PRC "buy votes" with aid and other goods (Woo and Chung 2018; Brazys and Dukalskis 2017).

29 The US Congress, for example, mandates annual reports that compare the US voting record to those of other member states, with particular emphasis on the voting records of US allies and various regional groupings, thus identifying "a country's orientation in world arenas: where it stands, with whom it stands (at least in a UN context), and for what purpose" (Department of State 2018: 3).
} 
and 30\% (Vietnam in 2017). As for exports, we see Laos and Myanmar sending between 30\% and $40 \%$ of the total to China. The figures for the rest are lower, ranging in any given year from around a quarter in the case of Japan to around 5\% in the case of Cambodia.

Figure 1 - Trade: US vs. China for 11 Asian States, 2010-2017

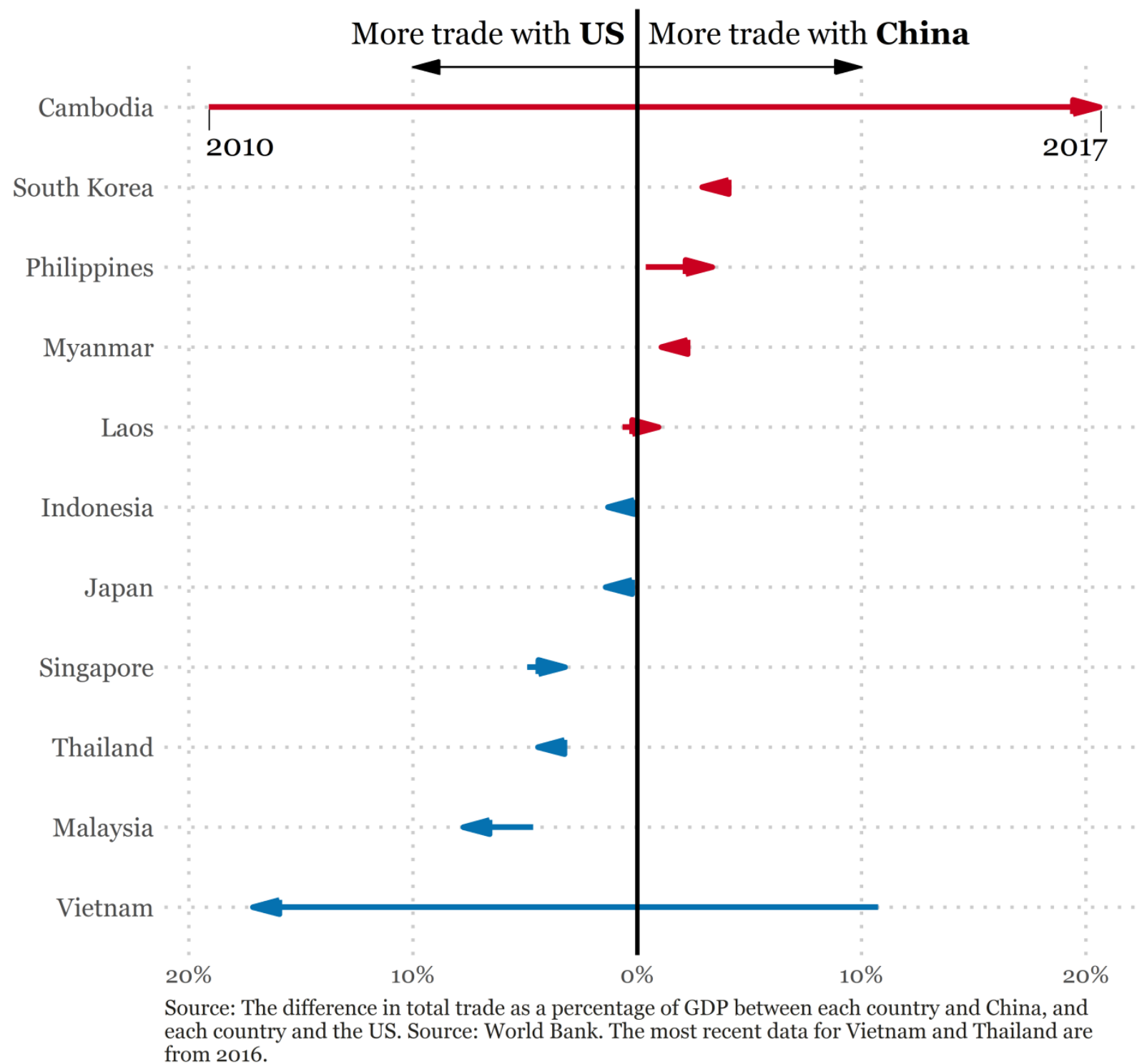

However, the US is the region's major trading partner, too. Figure 1 is a visualization of the difference in total trade as a percentage of GDP between the countries under study on the one hand and China and the US respectively on the other in the period between 2010 and 
2017.30 Here we see that only Cambodia experienced a significant shift in favor of China. The figures for the Philippines and Laos indicate the same, but to a much lesser degree. Conversely, the US in the same period gained a significant market share in Vietnam - a story that was frequently in the US news in the 2010s not because of the memories of the Vietnam War so much as the ballooning US trade deficit with the former enemy. In short, China's trading relations with the region are extensive, but so are US trading relations.

Moving on to FDI data, we see that the PRC is a major partner for Myanmar and Cambodia, where its firms make up between $20 \%$ and $30 \%$ of all foreign investment in the period under study. PRC investment is all-important in the case of Laos, where the latest (2017) figure is $97 \%$. Elsewhere in the region, Chinese FDI figures are lower, from around 15\% in Thailand to less than 1\% in Singapore, Japan, Indonesia, and the Philippines.

Similar to Figure 1, Figure 2 shows the difference in percentage change in FDI between the countries under study and China and the US, respectively. What we see here is that the volume of PRC FDI beat US FDI in five out of eight countries' cases. However, only in Cambodia and Vietnam is this difference visible. Indeed, much more remarkable was the increase of US FDI by $450 \%$ as seen above in Singapore, South Korea and Thailand. Here, too, we thus see that China's rise does not necessarily translate into domination, let alone hegemony. ${ }^{31}$ And this observation does not change even when we take into account the economic conditions behind the aforementioned debt-trap diplomacy. Only Laos and Cambodia are potential victims of said trap, given that around 20\% of their GDP is the PRC-held debt. Everywhere else in the region, the PRC-held debt is either small - the third-highest overall is Myanmar, at 5\% of GDP - or negligible.

\footnotetext{
30 The visualization idea behind Figures 1, 2, and 4 comes from Fisher and Carlsen (2018). Links to the raw data used is in Supplementary Files I https://srdjanvucetic.files.wordpress.com/2021/04/chinas-region-suppl.pdf

31 This is in line with Chong's (2020) analysis of trade and FDI patterns in Southeast Asia.
} 


\section{Figure 2 - FDI: US vs. China for 8 Asian States, 2010-2018}

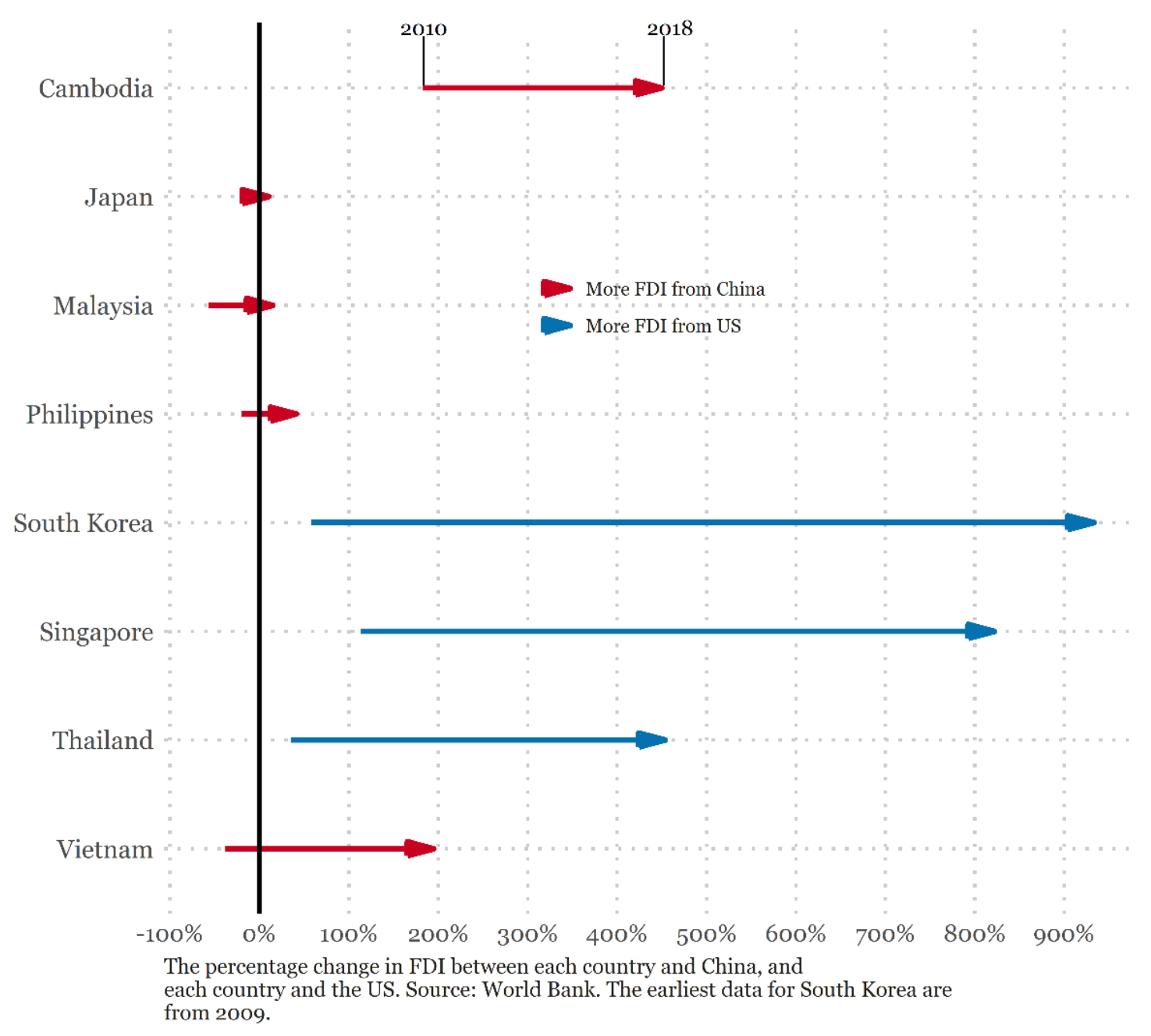

That economic relations are not suggestive of a coming Chinese hegemony can be also be gleaned from a quick historical comparison to the region the US claims as its own. Indeed, as dependent as the economies of Cambodia, Myanmar and Laos are on PRC trade, the equivalent figures for the US trade in the 1960s North America suggest what true hegemony-sustaining trade dependence looks like: 70\% for Canada and 60\% for Mexico. ${ }^{32}$ Similarly, no discussion of

\footnotetext{
32 Following this analogy, we might say that today's PRC trading power potential vis-à-vis its region is more akin to the mid-twentieth century US trading power over the countries of South America: sizeable but not towering. And keep in mind that my discussion does not account for the role of third states, such as Japan, the world's third largest economy and the region's trader par excellence that also competes with China in economic goods provision.
} 
economic goods provision can ignore the so-called "dollar hegemony" - a fact that large portions of global finance, payments and credit rely on the US currency. The strategic advantages that accrue to Washington as a result of this are old hat - hence the talk of "America's exorbitant privilege" in the 1960s (by French Finance Minister Giscard d'Estaing) and "super-exorbitant privilege" in the 1980s (by the British IR scholar Susan Strange). ${ }^{33}$ The global financial system's inequity is likely to continue well into the 2020s, which means that the US government will continue to use US financial institutions to punish actors with whom it fights or disagrees, be they states, groups or individuals. China and its strategic partners in Asia are no exception.

What of the forces of "deglobalization" associated with the 2008 global financial crisis and the subsequent rise of skepticism about free markets? The Trump administration, for one, unceremoniously withdrew the US from the Trans-Pacific Partnership in 2017, in turn giving China an opportunity to build an alternative trading network in the region. But this opportunity was short-lived. Reinvented as the Comprehensive and Progressive Agreement for Trans-Pacific Partnership, the TPP initiative has carried on, right through the US-China "trade war." Should the Biden administration decide to recommit the US to this agreement, US trade with the region would probably increase again, to the detriment of China's hegemonic prospects. ${ }^{34}$

\section{Security Goods}

To consider the regional supply-demand dynamics of security goods, let us start with the fact that the US remains the world's largest military spender, accounting for almost forty percent of total military expenditure in any given year from 2010. China's spending, the world's second-highest, amounts to about a third of US spending. ${ }^{35}$ That said, Chinese military power in the region has grown significantly since 2010. The PRC now accounts for half of all Asian

\footnotetext{
${ }^{33}$ See, inter alia, Norrlöf (2016) and Fichtner (2017).

34 The vaunted Sino-American "decoupling” never materialized at this time (Norrlöf and Poast 2020, Drezner 2019). Furthermore, the 2010s saw an increase in the use of US dollar in international trade, despite efforts of some major economies to "de-dollarize" and otherwise reduce vulnerability to the US (Ibid.)

35 As the latest SIPRI data show, "The United States spends more money on the military than the next 11 countries China, India, Russia, UK, Saudi Arabia, Germany, France, Japan, South Korea, Italy, and Australia - combined.” https://sipri.org/media/press-release/2021/world-military-spending-rises-almost-2-trillion-2020... Of course, these figures are contested; depending on the source, US military budget estimates range from 600 million per annum to over one trillion.
} 
military spending and its land, naval, air and cyber forces are all fielding new equipment, including some key anti-access/area-denial military technologies.

\section{Figure 3 - Military Expenditures in 2017 with \% change since 2014}

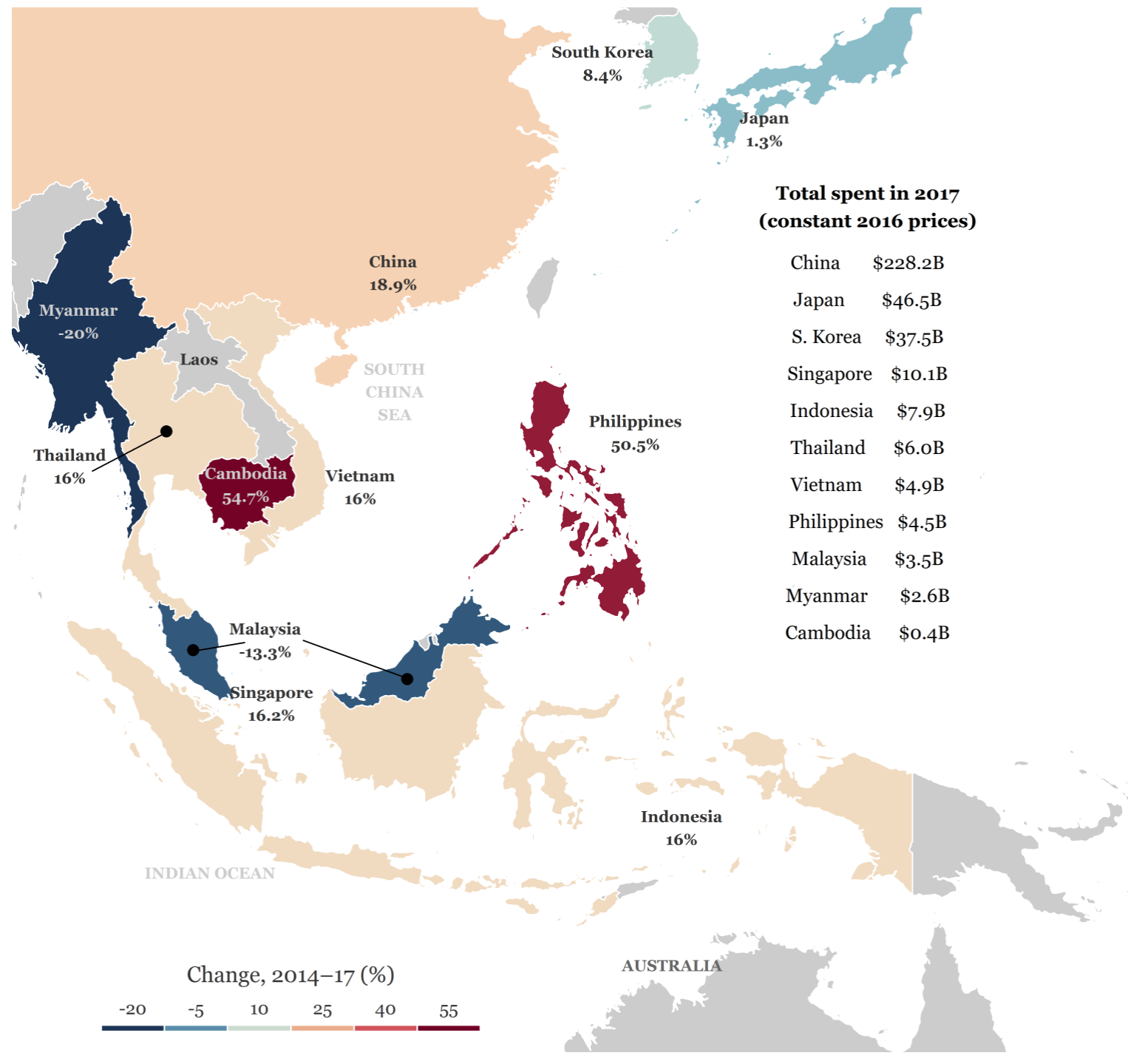

China has furthermore reclaimed over hundreds and even thousands of acres of real estate in the South China Sea, and placed new military capabilities there, including anti-ship missiles and long-range bombers. After Djibouti became the location of China's first overseas military base in 2017, more such bases are in the offing, especially in countries that fall along 
China's BRI corridors. In the region, these include a naval signals intelligence (SIGINT) facility in the Great Coco Island in Myanmar and the Ream naval base near Sihanoukville in Cambodia.

PRC military ambitions are one reason why military expenditure has grown across China's region since 2010-by around 70\% in East Asia and 60\% in Southeast Asia, according to SIPRI estimates. Figure 3 captures some of these changes over time, indicating that military spending increased in every country save for Malaysia and Myanmar, with China as a regional leader. Reputable military balance assessments also agree that the PRC's armed forces have steadily undercut US military superiority along China's coastline. However, the People's Liberation Army's bet on anti-access/area-denial systems is insufficient to change some basic geopolitical precepts. First, China's military power is hemmed in by a sprawling American system of alliances, permanent overseas bases, joint military exercises, training programs and other security arrangements. Second, Beijing's attempts to establish similar military-to-military ties in the region are undercut by its own strategy for long-term international cooperation, which explicitly forgoes "alliances" in favor of looser "strategic partnerships." Third, even if we assume that all of China's strategic partnerships have a security component, this network stills trail behind the US equivalent, either in terms of raw numbers or in terms of latent power. ${ }^{36}$ This context can serve as a corrective to a stream of sensationalist headlines about computersimulated wargames in the Western Pacific: absent a sudden arrival of some as yet unidentifiable "fourth offset" - an insider Washington term for the next game-changing generation of military technology - , the US and its allies are likely to maintain a huge technological and operational ability lead over virtually any opposing coalition led by the PRC. ${ }^{37}$

\footnotetext{
${ }^{36}$ Lie and Ye (2019) peg the number of China's strategic partnership at 78. By way of rough comparison, in 2017 the U.S-led "global coalition to counter the Islamic State" numbered 81 partner nations, while in 2021 over 100 nations agreed to take Afghan refugees and withdraw recognition of and/or aid to the Taliban government in Kabul. Of course, it can also be argued that such numeric comparisons are misleading because all complex hierarchies involve overlapping partnerships. We see this in the membership of China's Asian Infrastructure Investment Bank, a multilateral development bank established in 2014. For illuminating discussions, see Loke (2021), Johnston (2019) and Henke (2017).

${ }^{37}$ As far as I know, the fourth offset hypothetical comes from the Pentagon official Mieke Eoyang. For some military assessments, see Heginbotham et al (2015), Beckley (2018: Ch. 4), IISS (2019: Ch 6), Caverley and Dombrowski (2020), and Kuo (2021).
} 
Figure 4 - Arms sales: US vs. China for 10 states, 2010 - 2017

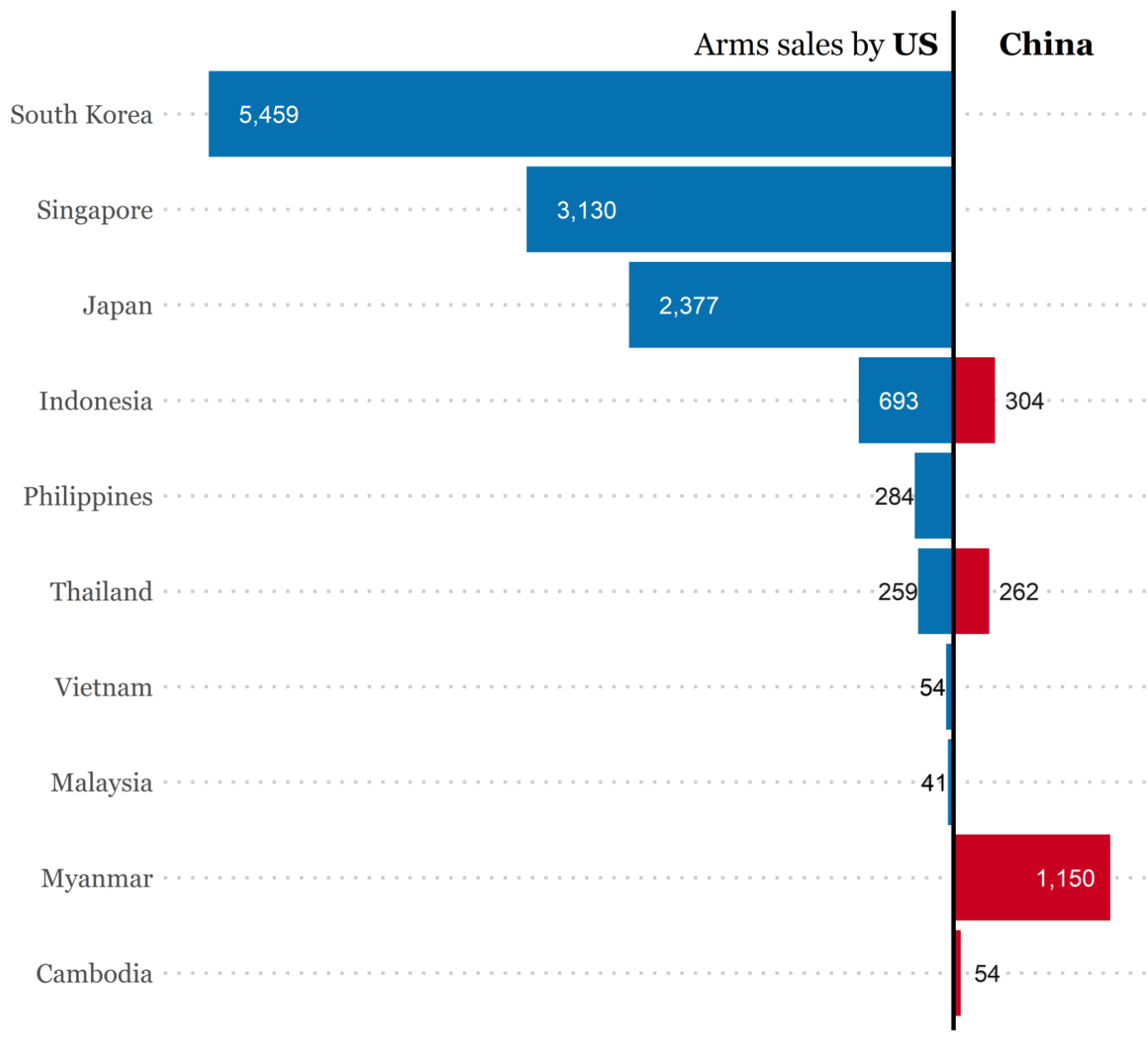

Source: Stockholm International Peace Research Institute.

Figures are SIPRI estimates (in USD millions) of total production costs from 2010 to 2017

Turning to arms trade, we see that the states in China's region are importing more weapons ${ }^{38}$, which in turn fuels the (talk of) arms races and security dilemmas. ${ }^{39}$ We also see that the PRC is now poised to become a top-three exporter of major conventional weapons such as ships and missiles, which is a feat considering that its armed forces have for decades been dependent on foreign and primarily Soviet and Russian military gear. However, most countries in the region continue to prefer US-built weapons over those supplied by PRC manufacturers. As shown in Figure 4, which is likewise based on SIPRI data, we see that four states listed source

\footnotetext{
${ }^{38}$ Holtom et al (2019).

39 Tan (2014); Liff and Ikenberry (2014).
} 
weapons in China and that only two - Cambodia and Myanmar - import exclusively from China. ${ }^{40}$ Even Vietnam, a top-ten importer of major conventional weapons in 2017 and a longtime Russian client, now sources some of its weapons from the US and none from the PRC. Military experts would likewise say that Figure 4 underestimates the power that accrues to the US through its military transfers to allies. Given the relative sophistication of the weapons systems the US sells, Singapore, South Korea or Japan are far more dependent on the US for the operation of their militaries than are Laos, Cambodia, and Myanmar on the PRC for theirs.

Given that most major conventional weapon transfers are also mini-alliances, ${ }^{41}$ Figure 4 also tells us that the US could conceivably hobble China's military rise by arming not only its treaty allies - Japan, South Korea, the Philippines, and Thailand -, but also some of its nontreaty and/or tacit allies, namely Vietnam, Indonesia, Malaysia and Singapore. I will return to this point below. For now, simply keep in mind that Japan, South Korea, and Vietnam are three of the top 15 military spenders in the world today, and that Singapore's high-tech military power is vastly disproportionate to the city state's size.

\section{Cultural Goods}

For insight into the distribution of "cultural goods" in the region, let us first turn to public-opinion polling data compiled by the Pew Research Centre. ${ }^{42}$ Countries surveyed varied from year to year, and this is reflected Figures 5 and 6 . As we can see in the former, "favorability" toward the PRC had both ups and downs over time. The median favorability for the PRC was highest in Malaysia, peaking in 2013 at over 80\%. Next comes Indonesia, peaking in 2013 at 70\%, but then precipitously dropping to less than 40\%. We see the same downward trend with the Philippines and South Korea, which both viewed the PRC with over 50\% favorability in 2015. Japan and Vietnam relatively low favorability of the PRC throughout.

\footnotetext{
${ }^{40}$ Laos also sources weapons in the PRC, albeit in smaller volume (31 million in total from 2010-17). Note again that SIPRI collects major conventional weapons data. It is possible that PRC transfers of small arms and light weapons to the region are more significant than their US and Western equivalents (United Nations, 2019).

41 Vucetic and Tago (2015). Note as well that both Republican and Democrat administrations have been shown no qualms about transferring weapon systems to major human rights-violating regimes in the region.

${ }^{42}$ On this and other global attitudes toward China data sources, see Princeton University's China Impact Project http://www.attitudetowardchina.com/map Supplementary Files at https://srdjanvucetic.wordpress.com/pew/
} 

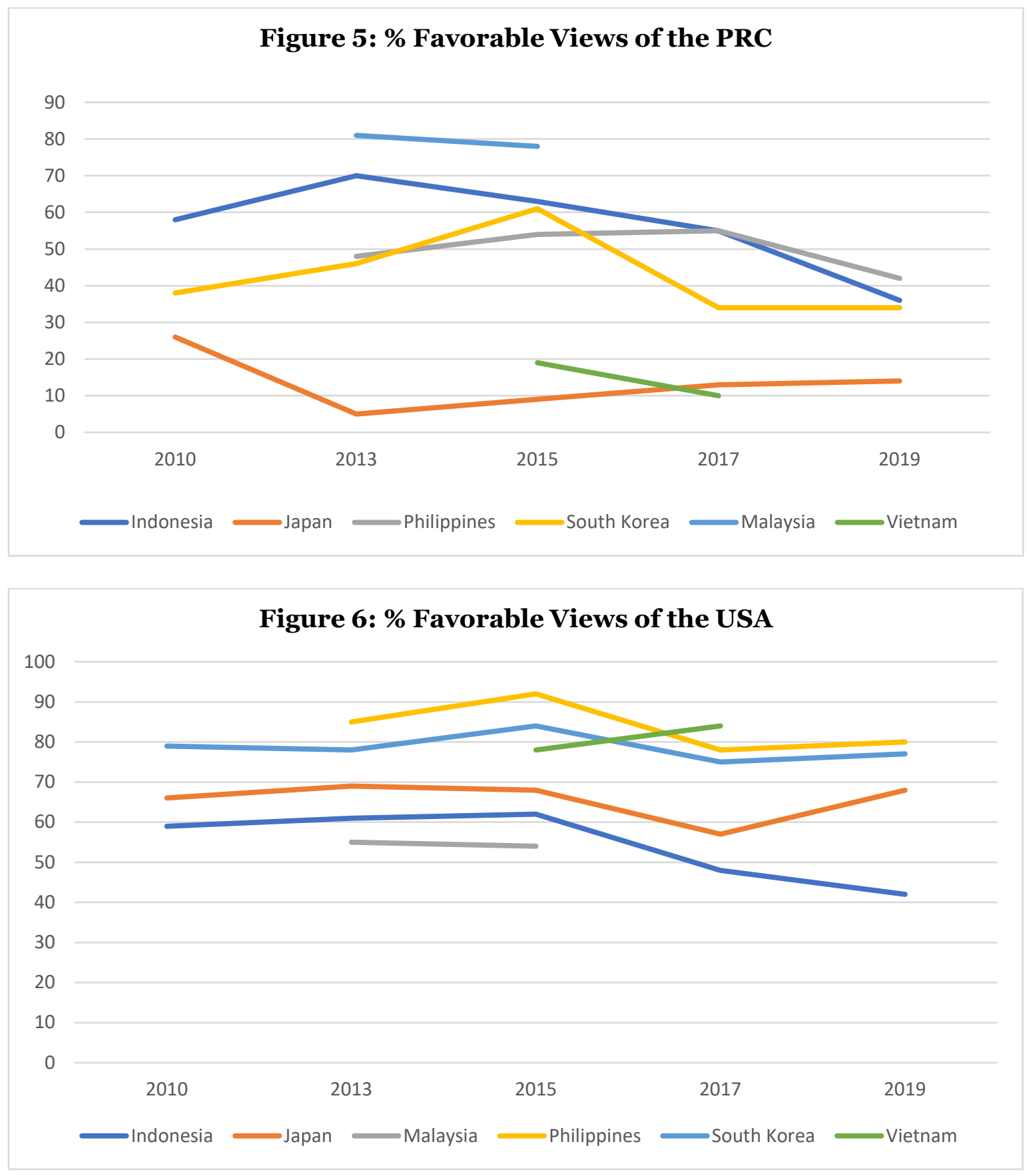

Looking at Figure 5 relative to Figure 6, however, we see that the favorability toward the US was consistently higher: 75\% and above in the Philippines, Vietnam and South Korea, between 60\% and 70\% in Japan, and above 50\% in Malaysia. Only in Indonesia do we see a decline to under 50\%, and this only in the period after 2015. In other words, we see that 
between on half and two thirds of respondents - this is the median figure for most countries in most years - favored the United States, versus one third to one tenth for China. ${ }^{43}$

Moving on to survey data beyond Pew, we see a broadly similar picture. Analyses of the Asia Barometer studies, Southeast Asian surveys by the National University of Singapore's ISEAS-Yusof Ishak Institute and the University of Tokyo's Asian Student Survey all reveal a sharp increase of negative evaluations of China over time. And although the same sources point to a rising discontent with the US over the course of the 2010s - the Trump factor at work - , the overall splits still tend to overwhelmingly favor of the US over the PRC. More speculatively, we might add that the news of China's COVID-19 cover-up and of genocidal repression of Muslim majority Uyghurs, together with some recent excesses of its "warrior diplomacy," have in fact made it easier for the US to maintain its public opinion favourability lead.

In sum, putting aside the value of this type of research for inferences about hegemony, the best available evidence suggests that "the Asians" - the scare quotes are necessary, for the term a great deal of heterogeneity - are guarded about Beijing's cultural goods-provision, today or in the foreseeable future. In contrast, UNGA voting data offer a more ambiguous picture. On one hand, the majority of the states under study consistently track PRC diplomatic positions, not US ones. On the other hand, a comparison of voting patterns tells us little about the prospects of PRC hegemony because of different conceptions of the function and practice of diplomacy held by the two rival powers. Let us consider each point in turn.

\footnotetext{
43 Pew data on "unfavorability" mostly mirror the above interpretation. Though in the Trump years perceptions of the US became more unfavorable in all surveyed cases, its median rating was still "better" than the equivalent for China. I put aside discussion of the pros and cons of using "net favorability" and "don't know" responses in such analyses. See Supplementary Files https://srdjanvucetic.wordpress.com/pew/
} 
Figure 7: Estimate of UNGA Voting Similarities, 2017

Sheet 1-72 (2017-18)

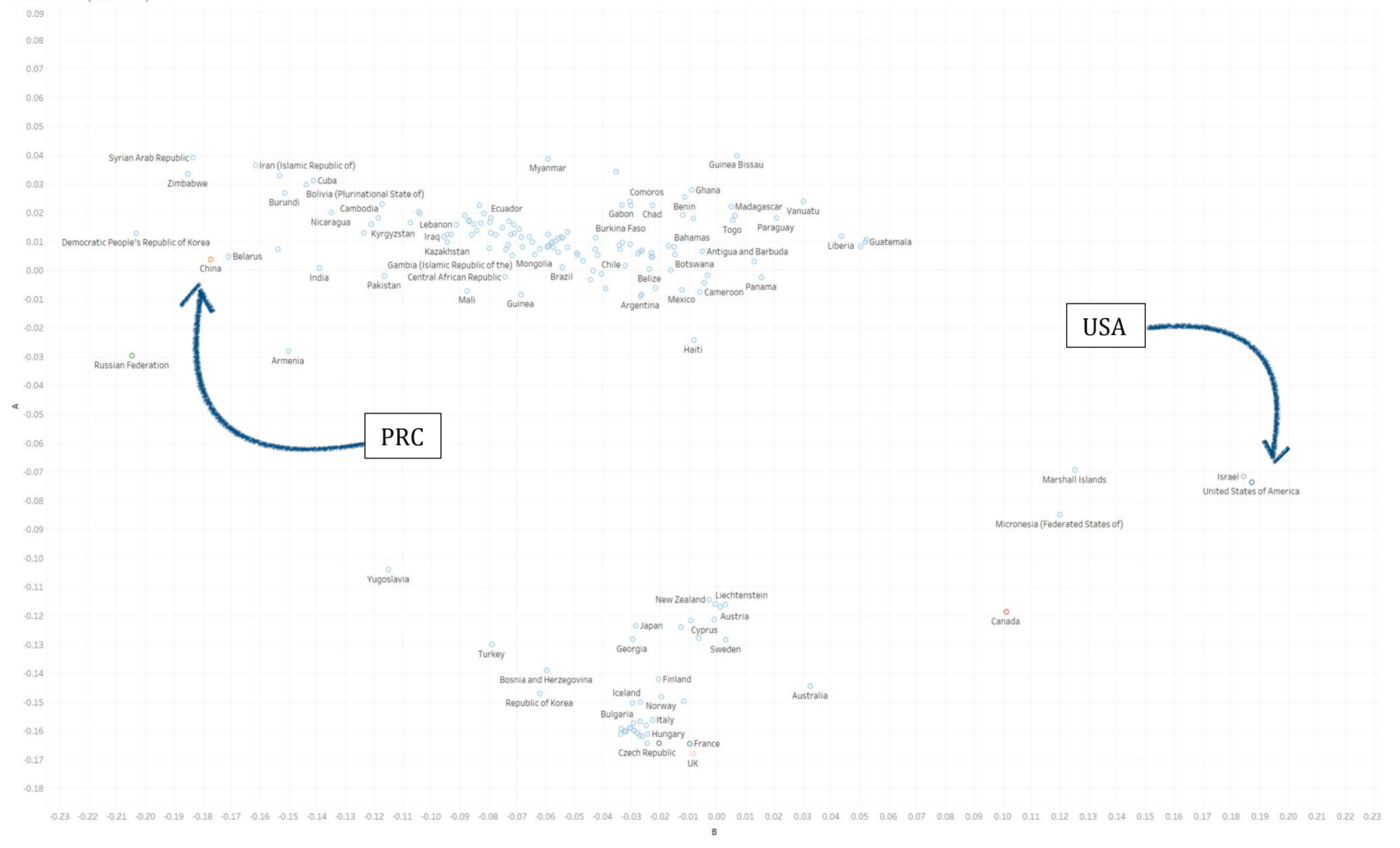


Figure 8: Estimate of UNGA Voting Similarities, 2010

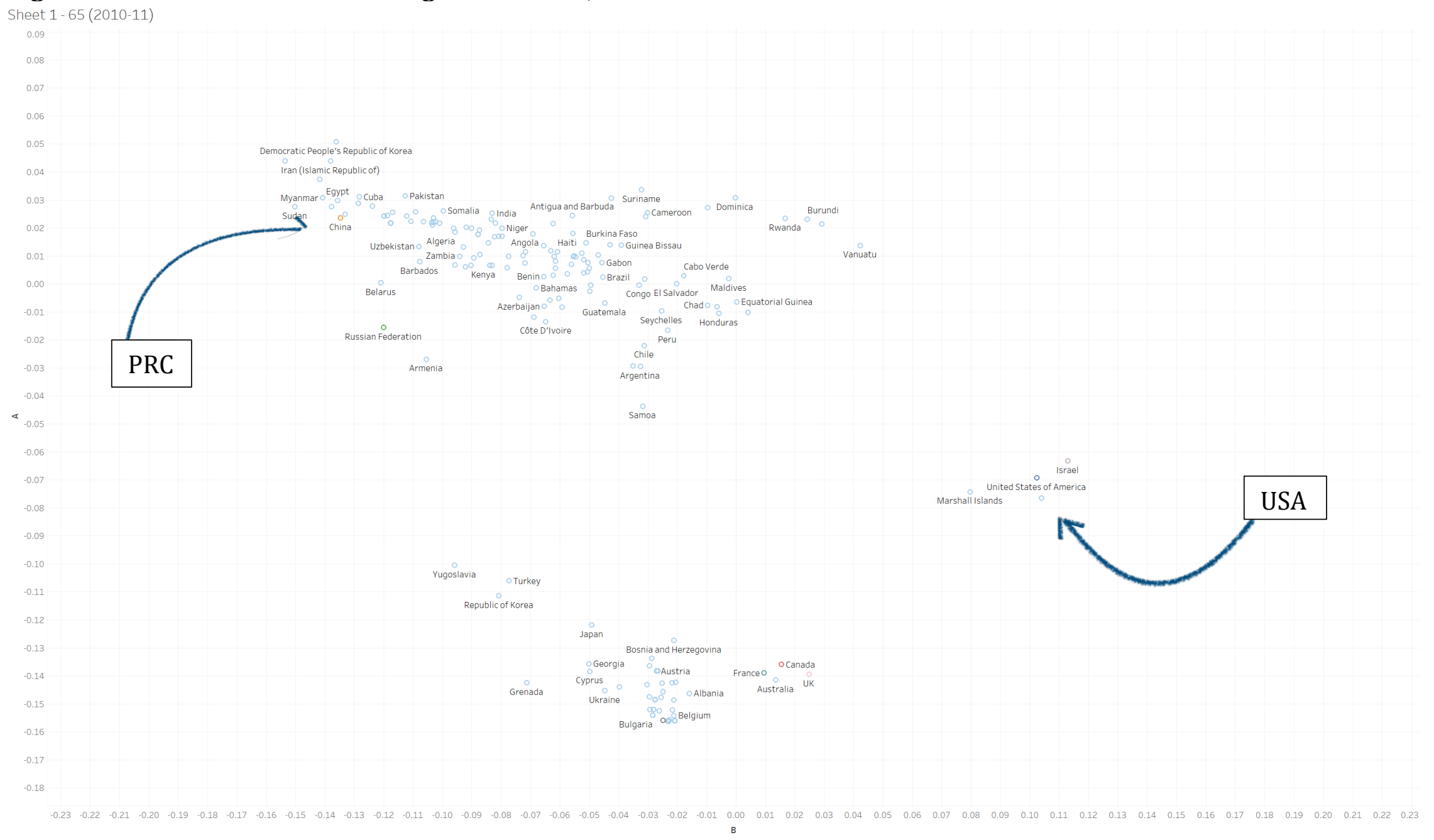


For breaking down UNGA voting data over time, I relied on Principal Component Analysis (PCA). ${ }^{44}$ Grounded in the principles of machine learning, PCA is useful for analyzing hegemonic relations because it clusters UNGA member states into groups inductively, that is, according to vote patterns themselves. Two key observations immediately emerge. First, the PRC is routinely much "closer" to the rest of the world than the US. We see this in Figures 7 and 8, which bookend the period under study by "freeze-framing" estimates of voting patterns in the 2017 and 2010 sessions of the UNGA, respectively. Second, Asia is no exception to this pattern. All being equal, most states in the region are much more likely to vote in line with the PRC than with the US.

$\begin{array}{lcccc}\text { Table 2: UNGA Voting Patterns Compared to USA versus PRC } \\ \begin{array}{l}\text { \% in Agreement, 2010-2017 } \\ \text { Country under study }\end{array} & \text { USA } & \text { USA } & \text { PRC } & \text { PRC } \\ & \text { Range } & \text { Average } & \text { Range } & \text { Average } \\ \text { Cambodia } & 6-17 & 10.6 & 43-80 & 58.7 \\ \text { Indonesia } & 7-14 & 10.5 & 52-79 & 61.3 \\ \text { Japan } & 15-33 & 25 & 33-54 & 40.2 \\ \text { Laos } & 4-13 & 8.3 & 49-77 & 58.7 \\ \text { Malaysia } & 7-18 & 11.8 & 51-74 & 60.8 \\ \text { Myanmar } & 6-17 & 11.2 & 47-67 & 56.4 \\ \text { Philippines } & 6-17 & 11.7 & 52-79 & 59 \\ \text { Singapore } & 7-19 & 12.1 & 53-80 & 60.6 \\ \text { South Korea } & 16-39 & 26.5 & 30-48 & 36.1 \\ \text { Thailand } & 7-20 & 12.8 & 51-78 & 59 \\ \text { Vietnam } & 5-15 & 10.3 & 51-79 & 60.2\end{array}$

To expand on PCA, consider Table 2, which presents the simple "percentage agreement” scores for the eleven states under study from 2008 to $2017 .{ }^{45}$ Here, too, we can make two observations. First, the dyadic scores for the PRC tend to be higher than the same scores for the

\footnotetext{
44 For discussion and application, see Vucetic and Ramadanovic (2020).

45 Even the highest individual scores for US dyads, Korea and Japan (around 25\%), were nowhere near as high as those for the "traditional" US allies in the UNGA, namely Israel, Micronesia, and the Marshal Islands (around 90\%). Raw data for Table 2 is available at https://srdjanvucetic.files.wordpress.com/2021/04/sv-ungadata-2019.xlsx
} 
US. Prime facie, this confirms the previous results: the foreign policy goals of most countries in the region converge more with Beijing than with Washington. ${ }^{46}$ Second, being a "key treaty ally" matters: Japan and South Korea consistently gravitate towards the US. The same does not hold for China's strategic partners. Indonesia (by average) and Cambodia (by range) have the most pro-PRC voting records, but only the latter is "a key strategic partner" to Beijing. ${ }^{47}$

Prima facie, Figures 7 and 8, as well as Table 2, suggest the PRC has more than a few followers the region. The qualifier "prima facie" is apt, however, for we must also consider the history and meaning of voting practices themselves. For one, ever since the PRC began working in, and with, the UN in 1974, its diplomats at the UNGA have had a tendency to track majority voting blocks, such as the Non-Aligned and/or the G77.48 US diplomats have followed the opposite path, reflecting and reinforcing the notion of American exemptionalism, a.k.a. exceptionalism. ${ }^{49}$ Crudely put, while the US views itself as "special" even with vis-à-vis "the West," the PRC tends to position itself as both a leader and follower of "the Rest." As so often the case with statistical analysis, basic history alerts us against overinterpreting and misreporting our results. The fact that UNGA diplomats are more likely to track Beijing's positions rather than those of the diplomatically self-isolated Washington cannot be taken as an indicator of China's power and US weakness. Rather, we must attribute this difference to complex historical processes of national and international-institutional political development. In addition to being important on its own terms, this qualification in turn confirms the validity of an approach that sets out to analyze hegemonic bids through multiple indicators at once.

\footnotetext{
${ }^{46}$ In terms of over-time trends, we see that pro-China voting peaked in 2014 and 2017 (The highest individual affinity score for China dyads were Cambodia and Singapore in 2017). For the US, there was an upward trend in the early 2010s and again in 2016. Supplementary Files, Figure S2 https://srdjanvucetic.files.wordpress.com/2021/04/chinasregion-suppl.pdf). These results are entirely in line with Fu (2018). See Supplementary Files, Tables S1 and S2 https://srdjanvucetic.files.wordpress.com/2021/04/chinas-region-suppl-second.pdf

47 These observations are not a function of the type of votes: they hold both on "all votes" and on "human rights votes," meaning on votes related to criticism of the human rights record of other member states. Note also that UNGA resolutions are usually divided into six key categories: security (including disarmament), decolonization, environment, Middle East (including Israeli-Palestinian conflict-related votes), UN internal issues, and human rights. 48 Kim (1999).

${ }^{49}$ Restad (2015).
} 


\section{Discussion}

Twenty-five years ago, China's economy firmly lagged behind that of Japan. Today, it is poised to dominate the world. This fact alone explains why we are seeing no shortage of knowledge production, academic and otherwise, on the future of international order and the respective role of China. While most observers agree that a material power shift away from the US and toward China is underway, there is considerable debate over what this means for international hegemony. Cooley and Nexon think the years of US global hegemony are numbered. They also think the geopolitical competition between the United States and China is playing out differently in different regions and across different issue areas, such that the talk of a "new Cold War" is premature.

The results of the present analysis supplement Cooley and Nexon's thesis. True, the old US-led international ordering is dying, and the new one is struggling to be born. But US hegemonic power is not poised to exit China's geopolitical neighborhood any time soon. Having analyzed the prevailing patterns in trade, FDI, external debt, financial flows, military balance, public opinion and UNGA voting over the course of the better part of the 2010s, we see that only Myanmar, Laos and Cambodia can be called the PRC's client states. The remaining eight nations, all of which are much wealthier and more technologically advanced than this trio, are pursuing a different strategic bargain: integrate with the PRC economically, but maintain legacy goods provision, too.

Although preliminary, this conclusion has two basic implications for contemporary IR debates. First, the economic, social, and cultural interconnectedness does not inspire leadership on its own. The PRC's mix of economic strength, military might, technological innovation, and infrastructure-first development policy is impressive, but its hegemonic potential is prima facie limited. Second and related, China's partial hegemony is partial even in Asia. This means that China's global hegemonic prospects are even poorer. To put it crudely, one cannot "rule the world" without ruling "own backyard" first.

Incidentally, this conclusion looks much less preliminary when situated against the backdrop of Western think tank knowledge production on China's rise. Consider the Council for 
Foreign Relations (CFR) "Belt and Road Tracker," a data analytic tool designed to trace the extent to which the PRC's BRI is changing countries' bilateral economic relationships with China over time. ${ }^{50}$ Looking at the countries' goods imports from China as a percentage of GDP, we can see that goods purchased from the PRC have spiked since the early 2010s. ${ }^{51}$ The same goes for FDI, with Chinese investment being the highest in Myanmar, which in some years received well over half of its inward FDI from the PRC. Chinese FDI has increased over time in Malaysia and Thailand, while falling in Cambodia from 9\% in 2010 to 3\% in 2017. Also useful is "The CFR Index of Debt to China," which is an in-house estimate of countries' stocks of external debt to China as a percentage of their GDP based on the CFR's own analysis of government announcements and media reports about Chinese development loans to BRI participants. The estimates are the same as mine: in Cambodia and Laos, the PRC-held debt hovered at 20\% of GDP in the period under study, followed by Myanmar, where it stood at 5\%. ${ }^{52}$

Brookings, another Washington-based think tank, analyzed the distribution of political preferences, and found that few, if any, actors in the region are welcoming of PRC influence. ${ }^{53}$ Whereas many perceive economic dependence on the PRC as "vulnerability to economic punishment”, only a minority frame equivalent dependence on the US and the West in like manner as opposed to, say, as a simple matter of globalization or, in fact, as an opportunity for economic growth. Together, these findings confirm what we discussed earlier. Yes, trade and FDI with, as well as debt to, the PRC all increased for most countries during the 2010s. However, most state leaders want to profit from China's rise while also maintaining a foreign

\footnotetext{
50 As its website says, the indicator “can be used to gauge a country's vulnerability to defaulting on Chinese debt, an eventuality which may result in China taking ownership of infrastructure." See https://www.cfr.org/article/belt-androad-tracker and Supplementary files https://srdjanvucetic.files.wordpress.com/2021/04/chinas-region-supplsecond.pdf The American Enterprise Institute (AEI) likewise collects this type of data. See http://www.aei.org/chinaglobal-investment-tracker/

51 The biggest shifts are in Cambodia, whose imports from China went from 8.9\% of GDP in 2009 to 21\% in 2017, as well as in Myanmar, the Philippines and Vietnam where imports from China doubled in the same period. Imports from China fell in Singapore, from a 2008 peak of $15.6 \%$ to $14.3 \%$ in 2017 . Downward trends for Chinese imports can be seen from 2015 to 2017 in Thailand and Indonesia (Steil and Della Rocca 2019).

52 Ibid.

53 Stromseth (2019).
} 
policy status quo. And only three countries - Myanmar, Cambodia and Laos - can be said to be heavily dependent on Chinese economic and security goods. ${ }^{54}$

Another think-tank analysis of relevance is the Lowy Institute Asia Power Index.

Ranking 25 countries and territories using over 125 factors across economic, military, diplomatic and other "thematic" measures of power, the Index is now updated annually and so subject to a regular stream of media commentary. The modal message sent is that there is a shrinking "power gap" between the US and PRC, with the latter's "overall influence" poised to reach parity or even surpass that of the former. ${ }^{55}$ Two points are worthy of special attention. First, Lowy researchers rank Myanmar, Cambodia, and Laos in the bottom fifth of the Index, labelling them "minor powers." Second, taking Lowy figures at face value, we see the region has more than one method of standing up to China. Even if the US, as Asia's “top-ranking” power, were to suddenly significantly scale back its presence there, the PRC would still be hard-pressed to coerce the remaining countries into its sphere of influence. Combing Lowy's analysis with mine, we might thus conclude that a likely group of "resisters" would encompass not only Japan, a country with a latent nuclear capability that Lowy experts label a "major power overachiever" and "the quintessential smart power," but also at least a dozen "middle powers." Here we have the "overachieving" South Korea and Singapore, the "underachievers," such as Malaysia, Indonesia, Thailand, and the Philippines, plus some major powers in Asia that fall outside the remit of the present analysis.

The last point invites us to ponder the role of Russia and India. On current trends, Moscow will continue to deepen its strategic partnership with Beijing, while New Delhi and Washington deepen theirs, both bilaterally and in terms of new multilateral arrangements, such as, for example, that between the US, Japan, Australia and India known as the Quad

\footnotetext{
${ }^{54}$ For the sake of brevity, I cannot detail the economic, security, and cultural relations among the 11 states under study themselves. Contemporary Cambodian foreign policy, for example, is shaped by the memories of Vietnam's occupation, 1978 -1989, as well as the border skirmishes with Thailand in 2011. has much to do with the latter's closeness to China today, for example.

55 The Index was introduced in 2018, and this paragraph is drawn from the 2019 version. The latest version encompasses 26 countries and 128 indicators https://power.lowyinstitute.org/ While heuristically useful, the Index is nevertheless rooted in contested concepts of power and influence. For some complications, see, inter alia, Allan, Vucetic, and Hopf (2018), Beckley (2018), Ross (2019) and Benabdallah (2020).
} 
(Quadrilateral Strategic Dialogue). The evolution of these and other strategic triangles and quadrangles - and of the "wedging" and "brokering" strategies that criss-cross and constitute them - will be one the key factors influencing the shape of Asia's hegemonic orderings. ${ }^{56}$

\section{Conclusion}

China's economic rise and military assertiveness have rightly inspired IR theorists to revisit theories of hegemony and hegemonic contestation. Building on Cooley and Nexon's framework, I have provided a preliminary assessment of the prospects of China's hegemony in East and South Asia, or China's own region. This is important because, in theory, locality allows potential hegemons to capitalize on its competitive advantages in economic, security and cultural interactions with neighboring states, thus building a potentially large pool of hegemonic followers.

The overall results suggest that an Asian Pax Sinica is yet to live up to its name. The PRC appears well-positioned to leverage its overwhelming material superiority for hegemonic purposes only in three states: Cambodia, Laos, and Myanmar. Elsewhere in the region, states are wary of Beijing's power and the potential for Chinese hegemony appears to be far more limited. We see this across economic, security, and cultural domains: although PRC-supplied goods are more significant than ever before, they are still not as significant as US- or Westernsupplied goods.

How long might these structural dynamics last? By all accounts, the US and PRC are poised to overcome most pandemic-related upheavals before most other countries. How this advantage might be translated into hegemonic provision of strategic goods is less clear. Under Biden, the US is more sharply focused on the Indo-Pacific than before. Claiming the need to "outcompete" China, the Democrat president has unveiled a multi-trillion-dollar infrastructure and spending agenda to boost the US economy and technological innovation. He has also set out

\footnotetext{
${ }^{56}$ Recall that Moscow and New Delhi have a long-standing strategic partnership, too. Brokered by the US or not, a hypothetical Indo-Russo alignment against the PRC would be fatal to the latter's hegemonic bid. For some context, see, inter alia, Cooley and Nexon (2020: 59-61), Karaganov (2020). Hall, ed. (2014) and Gilani (2021). Keep in mind as well the recent establishment of AUKUS, the "new" security pact of Australia, the UK and the US (cf. Vucetic 2011).
} 
to convene a virtual "Summit for Democracy" in turn signaling an end to Trump's policy of confrontation with allies and a renewed commitment to multilateralism.

Impressive as these "force multipliers" are in both principle and practice, the fact is that China will always have a greater long-term stake in Asia than the US. Should a future US administration decide that vigorous engagement in the region in the name of US global leadership is not worth the effort, the hegemony calculus would shift in Beijing's favor. Meanwhile, the mere availability of Chinese good provision might influence the region's geopolitical shape by giving states exit options and so expanding their room for strategic maneuver.

Amidst current and future competition, some degree of Sino-American cooperation will nevertheless be necessary to meet global challenges. Nowhere is this more evident than in efforts to combat the climate crisis. The fact that China emits more greenhouse gases than the entire developed world combined means the world's future depends on Beijing's ability and willingness to progressively cut emissions towards reaching carbon neutrality before 2060, as President Xi promised in 2020. This type of public good provision has a potential to win many hearts and minds globally, especially if PRC leadership demonstrates that it can simultaneously collaborate with the West and pressure own fossil fuel-producing strategic partners to meet increased emissions-reduction targets. For Beijing as well as for Washington, the path for greater influence is thus the same: steer the world towards cooperation, not competition. 


\section{Bibliography}

Abrahamsen, Rita, Jean-François Drolet, Alexandra Gheciu, Karin Narita, Srdjan Vucetic and Michael Williams. 2020. "Confronting the International Political Sociology of the New Right," International Political Sociology 14: 1, 94-107.

Allan, B., S. Vucetic and T. Hopf. 2018. Distribution of Identity and the Future of International Order: China's Hegemonic Prospects. International Organization, 72: 4, 839-869.

American Enterprise Institute. 2019. "Chinese Investment Dataset - China Global Investment Tracker." AEI. Accessed July 17 2019. http://www.aei.org/china-global-investment-tracker/

Andersen, Morten Skumsrud, Alexander Cooley, Daniel H. Nexon, eds. 2021. Undermining American Hegemony: Goods Substitution in World Politics. Cambridge: Cambridge University Press.

Andjelic, Neven 2020. "Hybrid Regimes of the Western Balkans: Reflection of a Global Geopolitical Struggle,” Journal of Regional Security 15 (2): 263-290.

Apostolov-Dimitrijevic, Dunja. 2020. Mapping the Global Balkans: The Governmentalities and Practices of Emerging Economy and EU Encounters in Serbia, PhD Dissertation, Political Science, Carleton University.

Bailey, Michael A, Anton Strezhnev and Erik Voeten. 2017. "Estimating Dynamic State Preferences from United Nations Voting Data.” Journal of Conflict Resolution 61(2):430-456.

Beckley, Michael. 2018. Unrivaled: Why America Will Remain the World's Sole Superpower. Ithaca, NY: Cornell University Press.

Benabdallah, Lina. 2020. Shaping the Future of Power: Knowledge Production and NetworkBuilding in China-Africa Relations. Ann Arbor: University of Michigan Press.

Beeson, Mark and Fujian Li. 2014. China's Regional Relations: Evolving Foreign Policy Dynamics, Boulder, CO: Lynne Rienner Publishers.

Brenner, David and Enze Han. 2021. "Forgotten Conflicts: Producing Knowledge and Ignorance in Security Studies," Journal of Global Security Studies, First View https://academic.oup.com/jogss/advance-article/doi/10.1093/jogss/ogab022/6369076

Brazys, Samuel, and Alexander Dukalskis. 2017. "Canary in the Coal Mine? China, the UNGA, and the Changing World Order." Review of International Studies 43 (4): 742-764. doi:10.1017/S0260210517000067

Buckley, Chris. 2013. "China Takes Aim at Western Ideas," New York Times, August 19. Accessed February 2020. https://www.nytimes.com/2013/08/20/world/asia/chinas-new-leadershiptakes-hard-line-in-secret-memo.html

Burzo, Stefano, and Xiaojun Li. 2018. "Public Perceptions of International Leadership in China and the United States," Chinese Political Science Review 3 (1): 81-99.

Búzás, Zoltan. 2020. Racism and Antiracism in the Liberal International Order. International Organization. FirstView online: 29 December 2020. 
Caverley, Jonathan D. and Peter Dombrowski. 2020. "Cruising for a Bruising: Maritime Competition in an Anti-Access Age," Security Studies 29: 4, 671-700.

CBC. 2019. "'White supremacy' a factor in detainees cases, Chinese ambassador to Canada says," CBC News, Jan 9. Accessed January 21, 2019. https://www.cbc.ca/news/politics/chinaambassador-white-supremacy-1.4971884

Chacko, Priya, and Kanishka Jayasuriya. 2017. “Trump, the authoritarian populist revolt and the future of the rules-based order in Asia." Australian Journal of International Affairs 71(2): 121127.

Chen, Ching-Chan. 2016. "East Asia: Understanding the Broken Harmony in Confucian Asia”. In The Palgrave Handbook of Disciplinary and Regional Approaches to Peace, edited by O.P. Richmond, S. Pogodda, J. Ramović, 350-362. London: Palgrave Macmillan.

Chong, Ja Ian. 2020. "PRC influence in Southeast Asia: no easy answers.” In China's Influences: Center-Periphery Tug-of-War across the Indo-Pacific, edited by Brian Fong, Wu Jieh-Min, and Andrew J. Nathan. Chapter 16. London: Routledge.

Chowdhury, Arjun. 2018. The myth of international order: Why weak states persist and alternatives to the state fade away. Oxford University Press.

Chu, Y.H, Kang, L. and Huang, M.H. 2015. "How East Asians View the Rise of China." Journal of Contemporary China 24 (93): 398-420.

Chu, Yun-han and Min-hua Huang. 2020. "How East Asians View a Rising China under the Leadership of Xi Jinping" in Soft Power with Chinese Characteristic, edited by Kingsley Edney, Stanley Rosen and Ying Zhu, 262-283. Routledge.

Cooley Alexander and Daniel Nexon. 2020. Exit from Hegemony: The Unraveling of the American Global Order. New York: Oxford University Press.

Cooley, Alexander, Daniel Nexon, and Stuart Ward. 2019. "Revising order or challenging the balance of military power? An alternative typology of revisionist and status-quo states," Review of International Studies 45(4): 1-20.

de Graaff, Nana, Tobias ten Brink and Inderjeet Parmar. 2020. “China's rise in a liberal world order in transition - introduction to the forum." Review of International Political Economy. 27 (2): 191-207. DOI: $\underline{10.1080 / 09692290.2019 .1709880}$

Drezner, Daniel W. 2019. "Counter-Hegemonic Strategies in the Global Economy." Security Studies, 28 (3): 505- 531.

Edney, Kingsley, Stanley Rosen and Ying Zhu, eds. 2020. Soft Power with Chinese Characteristics. London: Routledge.

European Thank-tank Network on China (ETNC). 2021, "China's Soft Power in Europe." Available from https://idos.gr/wp-content/uploads/2021/04/ETNC-2021-Chinas-Soft-Powerin-Europe-Falling-on-Hard-Times.pdf.

Feng, Huiyun and Kai He, eds. 2020. China's Challenges and International Order Transition: Beyond "Thucydides's Trap". Ann Arbor: University of Michigan Press.

Fichtner, Jan, 2017. "Perpetual decline or persistent dominance? Uncovering Anglo-America's true structural power in global finance." Review of international studies 43 (1): 3-28. 
Foot, Rosemary. 2020. “China's rise and US hegemony: Renegotiating hegemonic order in East Asia?. International Politics 57:2, 150-165.

Fu, Yiqin. 2018. "Data Analysis: Who Votes with China, and Who Votes with the US and Europe at the UN?," June 10. Available at https://yiqinfu.github.io/posts/united-nations-generalassembly/

Fukuyama, Francis. 2021. "A Highway in Montenegro and the Struggle with China” American Purpose, Accessed April 26, 2021 (blog post), Available at https://t.co/GwUDXvmbDs?amp=1

Gilani, Iftikhar. 2021. "India, China rivalry shifts to vaccine diplomacy.” Anadolu Agency, March https://www.aa.com.tr/en/asia-pacific/india-china-rivalry-shifts-to-vaccine diplomacy/2160364

Goh, Evelyn. 2019. "Contesting Hegemonic Order: China in East Asia." Security Studies, 28 (3): 614-644.

Gregorio Bettiza and David Lewis. 2020. "Authoritarian Powers and Norm Contestation in the Liberal International Order: Theorizing the Power Politics of Ideas and Identity". Journal of Global Security Studies Journal of Global Security Studies, 5 (4): 559-577.

Hall, Ian (ed.). 2014. The Engagement of India: Strategies and Responses. Washington DC: Georgetown University Press.

Heginbotham et al. 2015. The U.S.-China Military Scorecard: Forces, Geography, and the Evolving Balance of Power, 1996-2017. Santa Monica: Rand Corporation.

Henke, Marina. 2017. “The Politics of Diplomacy: How the United States Builds Multilateral Military Coalitions.” International Studies Quarterly 61(2): 410- 11.

Holtom, Paul et al. 2019. 'International arms transfers.' In SIPRI Yearbook 2019. Oxford: Oxford University Press.

Hoo, Tiang Boon. 2018. China's Global Identity: Considering the Responsibilities of Great Power Washington, DC: Georgetown University Press.

Hopf, Ted, and Bentley B. Allan, ed. 2016. Making Identity Count: Building a National Identity Database. Oxford: Oxford University Press.

Hurley, John, Scott Morris, and Gailyn Portelance, 2018. "Examining the Debt Implications of the Belt and Road Initiative from a Policy Perspective," Center for Global Development Research Paper

https://www.cgdev.org/publication/examining-debt-implications-belt-androad-initiative-apolicy-perspective

Fisher, Max and Audrey Carlsen. 2018. "How China Is Challenging American Dominance in Asia," New York Times, March 9. Available at https://www.nytimes.com/interactive/2018/03/09/world/asia/china-us-asia-rivalry.html.

Ikenberry, G. John, Jisi Wang and Feng Zhu. Eds. 2015. America, China, and the Struggle for World Order. New York: Palgrave Macmillan. 
International Institute for Strategic Studies. 2019. The Military Balance 2019. London. Routledge.

Johnston, Alastair Iain. 2019. "China in a World of Orders: Rethinking Compliance and Challenge in Beijing's International Relations,” International Security 44 (2), 9-60.

Jones, Lee Shahar Hameiri. 2020. Debunking the Myth of 'Debt-trap Diplomacy'. Chatham House Asia-Pacific Programme Research Paper. London. 44 pages.

Kang, David. 2007. China Rising: Peace, Power and Order in East Asia. New York: Columbia University Press.

Kapstein, E. B., J. Caverley and S. Vucetic. 2019. F-35 Sales are America's Belt and Road, Foreign Policy, July 12.

Karaganov, Sergei. 2020. The future of the big triangle. Russia in Global Affairs. Accessed 19 January 2021. https://eng.globalaffairs.ru/articles/future-big-triangle/.

Kim, S. S. 1999. "China and the United Nations." In China Joins the World: Progress and Prospects, edited by E. Economy, and M. Oksenberg, 42-89. New York: Council on Foreign Relations.

Kuo, Raymond. 2021. Contests of Initiative: Countering China's Gray Zone Strategy in the East and South China Seas. Westphalia Press.

Lai, Christina. 2018. "Acting one way and talking another: China's coercive economic diplomacy in East Asia and beyond." The Pacific Review 31(2): 169-187.

Li, Quan, and Ye, Min. 2019. "China's emerging partnership network: what, who, where, when and why." International Trade, Politics and Development, 3(2): 66-81.

Liang, Ce. 2018. "The Rise of China as a Constructed Narrative: Southeast Asia's response to Asia's power shift." The Pacific Review 31(3): 279-297.

Liff, Adam P and G John Ikenberry. 2014. "Racing toward Tragedy? China's Rise, Military Competition in the Asia Pacific, and the Security Dilemma." International Security, 39 (2): 52-91.

Loke, Beverley. 2021. "The United States, China, and the Politics of Hegemonic Ordering in East Asia”. International Studies Review, FirstView https://doi.org/10.1093/isr/viaa096

Mabee, Bryan. 2013. Understanding American Power: The Changing World of US Foreign Policy. London: Palgrave Macmillan.

Massie, Justin and Jonathan Paquin, eds. 2019. America's Allies and the Decline of US Hegemony. Abingdon, Oxon: Routledge.

Milanovic, Branko. 2020. The clash of capitalisms: The real fight for the global economy's future. Foreign Affairs, 99(1), 10-21.

Norrlöf, C. 2014. "Dollar Hegemony: A Power Analysis." Review of International Political Economy 21(5): 1042-70.

Norrlöf, C and Paul Poast 2020. "Introduction to Symposium on Global Monetary Order \& the Liberal Order Debate.” International Studies Perspectives 21(2): 109-114. 
Paris, Roland. 2020. “The Right to Dominate: How Old Ideas about Sovereignty Pose New Challenges for World Order," International Organization 74 (3): 453-489.

Prashad, Vijay. 2021. "Understanding the complicated politics and geopolitics of the coup in Myanmar.” New Europe, February 12. Available at

https://www.neweurope.eu/article/understanding-the-complicated-politics-and-geopolitics-ofthe-coup-in-myanmar/

Rolland, Nadège 2020. "China's Vision for a New World Order," The National Bureau of Asian Research report, January. https://www.nbr.org/publication/chinas-vision-for-a-new-worldorder/.

Popovic, Milos, Erin Jenne, and Juraj Medzihorsky, 2020. "Charm Offensive or Offensive Charm? An Analysis of Russian and Chinese Cultural Institutes Abroad," Europe-Asia Studies 72 (9), 1445-1467.

Prys, Miriam, 2010, "Hegemony, domination, detachment: Differences in regional powerhood," International Studies Review 12 (4), 479-504.

$\mathrm{Pu}$, Xiaoyu. 2019. Rebranding China: Contested Status Signaling in the Changing Global Order. Palo Alto, CA: Stanford University Press.

Restad, Hilde Eliassen. 2015. American Exceptionalism: An Idea that Made a Nation and Remade the World. Routledge.

Ross, Robert S. 2019. "On the Fungibility of Economic Power: China's Economic Rise and the East Asian Security Order.” European Journal of International Relations 25(1): 302-327.

Shambaugh, David, ed. 2006. Power Shift: China and Asia's New Dynamics. Berkeley, CA: University of California Press.

Seah, Sharon, Hoang Thi Ha, Melinda Martinus and Pham Thi Phuong Thao. 2021. The State of Southeast Asia: 2021. Singapore: ISEAS-Yusof Ishak Institute. Available at https://www.iseas.edu.sg/wp-content/uploads/2021/01/The-State-of-SEA-2021-v2.pdf

Silove, Nina. 2016. 'The Pivot before the pivot: U.S. Strategy to Preserve the Power Balance in Asia', International Security 40: 4, 45-88.

Steil, Benn and Benjamin Della Rocca. 2018. "Belt and Road Tracker," CFR. Accessed May 8, 2019. Available at https://www.cfr.org/article/belt-and-road-tracker

Sterling-Folker, Jennifer. 2009. 'Neoclassical Realism and Identity: Peril Despite Profit Across the Taiwan Strait', in Steven E. Lobell, Norrin M. Ripsman and Jeffrey W. Taliaferro (eds) Neoclassical Realism, the State, and Foreign Policy, 99-138. Cambridge University Press.

Stockholm International Peace Research Institute. Various Years. SIPRI Yearbooks 2010-2017, Armaments, Disarmament, and International Security. Oxford: Oxford University Press.

Stromseth, Jonathan. 2019. The Testing Ground: China's Rising Influence in Southeast Asia and Regional Responses. Global China, Brookings Institution (November), Available at https://www.brookings.edu/wpcontent/uploads/2019/11/FP 20191119 china se asia stro mseth.pdf

Tan, Andrew. 2014. The Arms Race in Asia: Trends, Causes and Implications. London: Routledge. 
Turner, Oliver and Inderjeet Parmar, eds. 2020. The United States in the Indo-Pacific: Obama's Legacy and the Trump Transition. Manchester: Manchester University Press.

Voeten, E. 2013. "Data and Analyses of Voting in the UN General Assembly." In Routledge Handbook of International Organization. London: Routledge.

Vucetic, S. 2011. The Anglosphere: A Genealogy of a Racialized Identity in International Relations. Stanford University Press.

Vucetic, S. 2021. "White Supremacy' in Hegemonic Contestations,” International System of Power - City University of London Blog, August 30.

https://blogs.city.ac.uk/internationalsystemofpower/2021/08/30/white-supremacy-inhegemonic-contestations/

Vucetic, S. and Atsushi Tago. 2015. "Why Buy American? The International Politics of Fighter Jet Transfers", Canadian Journal of Political Science 48: 1, 101-124.

Vucetic, S. and Bojan Ramadanovic. 2020. "Canada in the United Nations General Assembly from Trudeau to Trudeau,” Canadian Journal of Political Science 53: 1, 79-98.

Walton, David and Kavalski, Emilian, eds. 2017. Power Transition in Asia. London: Routledge.

Wang, Ban. Ed. 2017. Chinese Visions of World Order: Tianxia, Culture, and World Politics. Durham: Duke University Press.

Weiss, Jessica Chen and Jeremy L. Wallace. 2021. "Domestic Politics, China's Rise, and the Future of the Liberal International Order." International Organization, 75 (2): 635-664. DOI:10.1017/S002081832000048X

Woo, Byungwon \& Eunbin Chung. 2017. "Aid for Vote? United Nations General Assembly Voting and American Aid Allocation.” Political Studies 66 (4): 1002-1026.

Wong, Audrye. 2021. "How not to win allies and influence geopolitics," Foreign Affairs (May/June) https://www.foreignaffairs.com/articles/china/2021-04-20/how-not-win-alliesand-influence-geopolitics

Zhai, Yida. 2015. “Can power make a great state? Asian citizens' views of China's power”. Issues \& Studies, 51 (4): 85-117.

Zhai, Yida. 2018. "The Gap in Viewing China's Rise between Chinese Youth and Their Asian Counterparts," Journal of Contemporary China 27 (144), 848-866.

Zhang, Feng. 2018. "Is Southeast Asia Really Balancing against China?" The Washington Quarterly 41(3): 191-204. 